\title{
Brain Stem Glioma
}

National Cancer Institute

\section{Source}

National Cancer Institute. Brain Stem Glioma. NCI Thesaurus. Code C8501.

A glioma that arises from the brain stem. 